\title{
FAKTOR - FAKTOR YANG MEMPENGARUHI TURNOVER INTENTION KARYAWAN PADA HOTEL BINTANG TIGA DI KOTA PADANG
}

\author{
Shelinda Rahman \\ Universitas Andalas, Indonesia \\ Shelindarahman21@gmail.com \\ Harif Amali Rivai \\ Universitas Andalas, Indonesia \\ harifamali@gmail.com
}

\begin{abstract}
ABSTRAK
Sumber daya manusia memiliki peranan penting dalam suatu organisasi baik organisasi dalam skala besar maupu skala kecil. Dunia persaingan usaha yang semakin ketat, organisasi berusaha meminimalkan rasio turnover dan menghemat biaya mereka, biaya turnover terdiri dari merekrut ulang karyawan dan biaya pelatihan kembali. Penelitian ini bertujuan menganalisis pengaruh kepuasan pelatihan, kepuasan gaji, dan kepuasan kerja terhadap intensi turnover dengan komitmen organisasional sebagai variabel mediasi pada karyawan hotel bintang tiga di Kota Padang. Dengan total responden sebanyak 140 orang Pengujian validitas sampel dilakukan dengan uji loading factor dan average variance extracted (AVE) sedangkan pengujian reliabilitas menggunakan uji internal consistency berdasarkan nilai composite reliability. Uji validitas dengan loading factor menunjukkan nilai yang valid. Pengujian reliabilitas dengan uji internal consistency mempunyai nilai composite reliability yang memenuhi kriteria. Berdasarkan hasil pengujian, semua pernyataan indikator variabel telah memenuhi kriteria validitas dan reliabilitas. Hasil uji hipotesis dengan SmartPLS menunjukkan bahwa komitmen organisasional, kepuasan pelatihan, dan kepuasan gaji berpengaruh negatif dan signifikan terhadap turnover intention. Komitmen organisasional memediasi hubungan kepuasan pelatihan, kepuasan gaji, terhadap turnover intention.
\end{abstract}

Kata Kunci: Kepuasan pelatihan, kepuasan gaji, komitmen organisasional, turnover intention, SmartPLS.

\begin{abstract}
Human resources have an important role in an organization both large and small scale organizations. The world of tough competition the organizations try to minimize their turnover ratio and save their cost, turnover cost consists of re-recruiting employees and retraining costs. The purpose of this research is to understand and analyze the effects of training satisfaction, pay satisfaction and job satisfaction to employee turnover intention with organizational commitment as a mediating variable in the three-star hotel employess in Padang city. With a total of 140 respondents the sample validity testing was carried out by loading factor and average variance extracted (AVE) while the reliability testing used an internal consistency test based on composite reliability values. Validity test with loading factor shows a valid value. Reliability testing with internal consistency test has composite reliability values that meet the criteria. Based on the test results, all variable indicator statements have met the criteria of validity and reliability. Hypothesis test results with SmartPLS show that organizational commitment, training satisfaction and salary satisfaction have a negative and significant effect on turnover intention. Organizational commitment mediates the relationship of training satisfaction, salary satisfaction, and job satisfaction on turnover intention.
\end{abstract}

Keywords: Training satisfaction, pay satisfaction, organizational commitment, turnover intention, SmartPLS. 


\section{PENDAHULUAN}

Dewasa ini persaingan dalam dunia usaha sangat ketat. Dalam iklim bisnis yang kompetitif ini, agar perusahaan dapat beroperasi dengan baik tidak hanya dilihat berdasarkan kemampuan finansial saja, tetapi diperlukan sumber daya manusia yang kompeten dan berkualitas untuk mengelola kegiatan perusahaan. Di lihat dari sudut pandang organisasi, mempertahankan karyawan terbaik sama pentingnya dengan mengimbangi kemajuan tekhnologi.

Terlepas dari langkah-langkah yang dipilih oleh organisasi untuk mempertahankan karyawannya, turnover intention adalah sebuah masalah yang muncul terus menerus terjadi pada sebagian besar organisasi. Intensi turnover mengacu pada keinginan sadar dan sengaja untuk meninggalkan organisasi dan telah menjadi salah satu tantangan utama yang dihadapi organisasi (Huang \& Su, 2016). Pertumbuhan angka pergantian karyawan yang tinggi dapat menghambat kualitas, konsitensi, dan stabilitas layanan yang organisasi berikan kepada pelanggan yang pada akhirnya mengarah kepada ketidakpuasan pelanggan. Dilihat dari kondisi tersebut, pergantian yang berlebihan dapat berakibat fatal bagi organisasi 64 dikarenakan kurangnya keahlian di pasar kerja dihadapkan dengan tingginya biaya pelatihan karyawan baru.

Dengan tingginya angka turnover suatu perusahaan mengakibatkan banyaknya perusahaan yang mengalami kerugian, fenomena ini salah satunya sering terjadi pada sektor perhotelan. Meningkatnya pertumbuhan perhotelan di kota Padang, maka hal ini bisa menyebabkan bertambah ketatnya persaingan di dalam industri perhotelan tersebut. Sumber daya manusia menjadi salah satu bagian utama dari produk yang melakukan peran yang sulit untuk meningkatkan citra organisasi. Salah satu faktor terpenting dalam keberhasilan industri perhotelan adalah karyawan. Daya saing organisasi pariwisata dan kelangsungan hidup mereka bergantung pada kualitas layanan yang mereka tawarkan. Dalam hal ini, industri perhotelan tidak hanya perlu melatih karyawan yang menjalankan peran mereka secara efektif tetapi juga harus mempertahankan staf mereka (Subramanian \& Shin, 2013). Meningkatnya pertumbuhan perhotelan di kota Padang, maka hal ini bisa menyebabkan bertambah ketatnya persaingan di dalam industri perhotelan tersebut. Sumber daya manusia menjadi salah satu bagian utama 
Tabel 1. Persentase Turnover Karyawan di Hotel bintang 3 di Kota Padang

\begin{tabular}{cccc}
\hline & \multicolumn{3}{c}{ Persentase } \\
\cline { 2 - 4 } Nama Hotel & $\mathbf{2 0 1 7}$ & $\mathbf{2 0 1 8}$ & $\begin{array}{c}\text { Agustus } \\
\mathbf{2 0 1 9}\end{array}$ \\
\hline Daima Hotel & $11.11 \%$ & $6.04 \%$ & $13.71 \%$ \\
Kawana Hotel & $9.69 \%$ & $14.72 \%$ & $6.67 \%$ \\
$\begin{array}{c}\text { Rangkayo Baso } \\
\text { Halal Hotel }\end{array}$ & $6.6 \%$ & $14.3 \%$ & $10 \%$ \\
\hline Sumber: HRD Setiap Hotel Bintang Tiga di Kota \\
& Padang, 2019
\end{tabular}

dari produk yang melakukan peran yang sulit untuk meningkatkan citra organisasi.

Berdasarkan perhitungan, presentase tingkat turnover karyawan hotel bintang tiga mengalami fluktuasi yang cukup tinggi. Tingkat rata-rata turnover karyawan pada 3 tahun terakhir di Hotel Daima, Kawana, dan Rangkayo Basa telah melebihi standar yang ditolerir. tingkat turnover dikatakan tinggi apabila melebihi $10 \%$ setiap tahunnya.

Faktor penentu seseorang pindah kerja tidak dapat dipungkiri salah satunya adalah training satisfaction. Biasanya produktivitas seorang pekerja akan meningkat setelah mengikuti program pelatihan. Perusahaan berinvestasi dalam sumber daya manusia mereka untuk meningkatkan nilai pekerja, dalam hal kinerja dan produktivitas kerja, dan selanjutnya untuk mencapai keunggulan kompetitif. Pada waktu bersamaan, meningkatkan produktivitas melalui pelatihan dapat memengaruhi turnover intention dengan meningkatkan kemampuan kerja pekerja di perusahaan lain (Verhees, 2012).

Banyak hal yang mempengaruhi terjadinya turnover intention dalam perhotelan. Salah satunya adalah job satisfaction. Putri \& Rivai (2019) berpendapat bahwa timbulnya turnover intention pada karyawan dalam sebuah perusahaan, sangat berkaitan erat dengan kepuasan dan ketidakpuasan karyawan terhadap pekerjaannya. Apabila karyawan puas akan berbagai dimensi pekerjaan mereka tidak akan mencari pekerjaan lain. Sebaliknya, apabila karyawan merasa tidak puas terhadap pekerjaan yang telah dilakukannya, maka akan menyebabkan keinginan berpindah serta hilangnya komitmen organisasi.

Siwi, Taroreh \& Dotulong (2016) berpendapat bahwa mempertahankan bakat adalah hal yang penting untuk manajer di semua jenis organisasi. Biaya yang terkait dengan kehilangan karyawan dan merekrut, memilih dan melatih karyawan yang baru sering melebihi $100 \%$ dari kompensasi tahunan untuk posisi tersebut. Gaji hampir selalu menjadi alasan seseorang untuk keluar dari pekerjaannya. Beberapa karyawan 
berhenti karena merasa tidak puas akan gaji yang diberikan dan seringkali seseorang sering berhenti atau keluar dari pekerjaannya sekarang untuk menerima tawaran bayaran yang lebih tinggi dari pekerjaan ditempat lain.

Hal yang juga penting untuk diperhatikan industri perhotelan dalam mempertahankan karyawan adalah komitmen karyawan yang menjadi sangat penting untuk kelangsungan hidup bisnis apa pun terutama di kondisi yang mengglobal ini. Karyawan yang mempunyai komitmen terhadap organisasi cenderung menunjukan sikap kerja yang semangat terhadap tugas yang diberikan dan memiliki tanggung jawab serta sangat loyal terhadap perusahaan. Dan untuk memperbaiki masalah dengan tunover intentions ini, para pemimpin dapat mengembangkan dan menerapkan strategi untuk meningkatkan hubungan dengan karyawan.

Berdasarkan latar belakang yang telah dipaparkan di atas, maka penelitian ini akan mengkaji mengenai pengaruh antara Kepuasan Pelatihan dan Kepuasan Gaji terhadap Turnover Itention Melalui Komitmen Organisasional Sebagai Variabel Mediasi. Maka dari itu, penulis tertarik untuk mengetahui lebih lanjut mengenai hal tersebut 66 dengan menjadikan karyawan hotel bintang tiga di kota Padang sebagai tempat penelitian.

\section{$\begin{array}{lll}\text { TINJAUAN TEORI DAN } & \end{array}$} PENGEMBANGAN HIPOTESIS

Kepuasan Pelatihan

Kepuasan pelatihan didefinisikan sebagai sejauh mana orang menyukai atau tidak menyukai seperangkat kegiatan yang direncanakan dan disusun untuk mengembangkan pengetahuan, keterampilan, dan sikap yang diperlukan untuk secara efektif melakukan tugas atau pekerjaan tertentu (Schmidt, 2007). Indikator dalam variabel ini berdasarkan pada Schmidt (2007) adalah Organizational support for training, Employee feelings about training, dan Employee satisfaction with training.

\section{Kepuasan Gaji}

Menurut Lum et al (1999 dalam Susetyo, 2016) menyatakan bahwa kepuasan gaji dapat diartikan bahwa seseorang akan terpuaskan dengan gajinya ketika persepsi terhadap gaji dan apa yang mereka peroleh sesuai dengan yang diharapkan. Menurut Salleh \& Memon (2015) dimensi kepuasan gaji terbagi atas empat dimensi yang terbagi sebagai berikut: (1) Tingkat Gaji (pay level), 
yaitu seberapa besar keadilan dalam penerimaan upah karyawan; (2) Kompensasi (benefits) yaitu seberapa keuntungan atau manfaat yang diterima oleh karyawan; (3) Kenaikan Gaji (pay raise) yaitu seberapa besar kenaikan upah yang sesuai dengan kebutuhan; (4) Struktur dan Administrasi Penggajian (Pay structure and administration) yaitu bagaimana memberikan nilai besar kecilnya upah atau gaji berdasarkan tingkat atau kedudukannya dalam suatu perusahaan.

\section{Komitmen Organisasional}

Komitmen organisasi didefinisikan sebagai perasaan kewajiban karyawan untuk tetap bersama organisasi. Dengan kata lain, ada unsur loyalitas di dalamnya terhadap tujuan dan juga nilai dari perusahaan ia bekerja. Komitmen organisasional merupakan sikap kesetiaan karyawan kepada organisasinya, dan mengungkap perhatian pada keberhasilan dan kesejahteraan organisasi (Yousef, 2017). Dimensi komitmen organisasional menurut Yücel (2012) terbagi atas tiga dimensi yang terbagi sebagai berikut:

\section{Affective Commitment}

Perasaan emosional untuk organisasi dan keyakinan dalam nilai-nilai. terjadi apabila karyawan ingin menjadi bagian dari organisasi karena adanya ikatan emosional. Anggota organisasi dengan komitmen afektif yang tinggi akan terus menjadi anggota dalam organisasi karena memang memiliki keinginan untuk itu.

\section{Continuance Commitment}

Terjadi apabila karyawan tetap bertahan pada suatu organisasi karena membutuhkan gaji dan keuntungankeuntungan lain, atau karena karyawan tersebut tidak menemukan pekerjaan lain. Anggota organisasi dengan komitmen kontinuan yang tinggi akan terus menjadi anggota dalam organisasinya karena mereka memiliki kebutuhan untuk menjadi anggota organisasi tersebut.

\section{Normative Commitment}

Kewajiban untuk bertahan dalam organisasi untuk alasan-alasan moral atau etis. Perasaan yang mengharuskan untuk bertahan dalam organisasi dikarenakan kewajiban dan tanggung jawab terhadap organisasi yang didasari atas pertimbangan norma, nilai, dan keyakinan karyawan. 


\section{Turnover Intention}

Turnover intention dan intention to quit merupakan sebuah fenomena yang sering terjadi di dalam sebuah perusahaan, ketika karyawan secara serius mempertimbangkan untuk berhenti dari pekerjaan mereka, maka mereka dianggap memiliki niat untuk keluar dari organisasi. Istilah "niat" ini yang menggambarkan kesengajaan karyawan untuk meninggalkan organisasi (Yamazakia \& Petchdee, 2015). Menurut Abelson (dalam Susetyo, 2016), dalam mengelompokkan berhentinya karyawan dari perusahaan berdasarkan siapa yang memunculkan inisiatif untuk berhenti kerja, terdiri dari 2 kategori yaitu: (1) Turnover yang terjadi sukarela (voluntary turnover), terjadi apabila karyawan memutuskan baik secara personal ataupun disebabkan oleh alasan profesional lainnya untuk menghentikan hubungan kerja dengan perusahaan, misalnya karyawan berkeinginan untuk mendapatkan pekerjaan dengan gaji yang lebih baik ditempat lain; (2) Turnover yang dipisahkan (involuntary turnover), keluarnya karyawan dari organisasi karena diberhentikan oleh perusahaan yang bersangkutan, biasanya seperti pemutusan hubungan kerja.

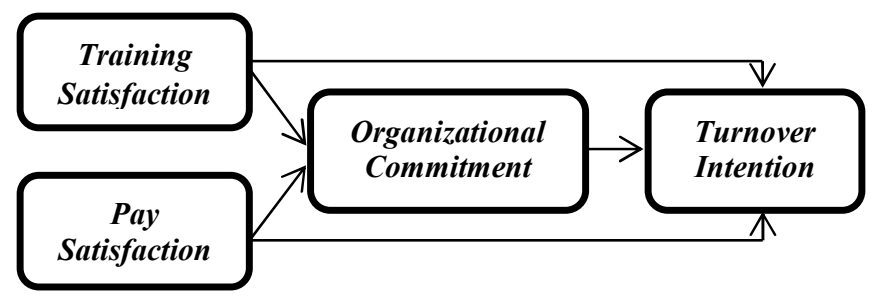

\section{Gambar 1. Model Penelitian}

\section{Pengembangan Hipotesis}

$H 1$ : Komitmen organisasional berpengaruh negatif terhadap turnover intention pada karyawan hotel bintang tiga di kota Padang.

H2 : Kepuasan pelatihan berpengaruh negatif terhadap turnover intention pada karyawan hotel bintang tiga di kota Padang.

H3 : Kepuasan gaji berpengaruh negatif terhadap turnover intention pada karyawan hotel bintang tiga di kota Padang.

H4 : Komitmen organisasional memediasi pengaruh kepuasan pelatihan terhadap turnover intention pada karyawan hotel bintang tiga di kota Padang.

H5 : Komitmen organisasional memediasi pengaruh kepuasan gaji terhadap turnover intention pada karyawan hotel bintang tiga di kota Padang. 


\section{METODE RISET}

Penelitian ini akan menjadikan karyawan hotel bintang tiga di kota Padang sebagai objek penelitian. Adapun sampel pada penelitian ini adalah seluruh karyawan yang berada pada hotel baik yang berstatus karyawan tetap maupun kontrak sejumlah 160 karyawan.

\section{Pengukuran dan Defenisi Operasional}

\section{Variabel Penelitian}

Variabel pengukuran kepuasan pelatihan, kepuasan gaji, kepuasan kerja, komitmen organisasional dan turnover intention diadopsi dan dikembangkan berdasarkan variabel yang sudah ada dari penelitian sebelumnya. Kuesioner dalam penelitian ini disusun dengan menggunakan skala Likert bernilai 1 poin hingga 5 poin pada tiap-tiap pertanyaan, dimulai dari sangat tidak setuju, tidak setuju, netral, setuju dan sangat setuju. Variabel Kepuasan pelatihan terdiri dari empat-item skala yang diadaptasi dari Schimdt (2007). Variabel Kepuasan gaji diukur dengan menggunakan empat dimensi Pay Satisfaction Quistionnaire yang dikembangkan oleh Heneman dan Schwab (1985) yang digunakan untuk mengukur kepuasan gaji. Kepuasan kerja diukur dengan lima-item yang dikembangkan oleh Schimdt (2007) yang digunakan untuk menilai kepuasan kerja. Item ini termasuk aspek kepuasan intrinsik dan kepuasan ekstrinsik. Sedangkan, komitmen organisasional diukur dengan menggunakan skala komitmen organisasi yang dikembangkan oleh Meyer dan Allen (1990), yang telah menunjukkan keandalan dan validitas yang baik oleh penelitian yang cukup besar. Skala ini mencakup tiga dimensi yaitu komitmen afektif, komitmen kelanjutan dan komitmen normatif. Dan komitmen turnover intention diukur dengan skala 3-item yang berisi informasi tentang niat individu untuk mencari pekerjaan lain dan kemungkinan mereka meninggalkan organisasi saat ini. Item diadaptasi dari Lum et al. (1998) yang mempelajari turnover intention pada lingkungan kerja rumah sakit.

\section{Teknik Analisis Data}

Model penelitian ini akan dianalisa menggunakan teknik Structural Equation Model (SEM), dengan menggunakan bantuan SmartPLS. Manfaat utama SEM dibandingkan dengan generasi pertama multivariate seperti principal componenent analiysis, factor analysis, discriminant analysis dan multiple 
regression, SEM memiliki fleksibilitas yang lebih tinggi bagi peneliti untuk menghubungkan antara teori dan data (Ghozali and Latan, 2015).

Pada pengujian melalui aplikasi ini ada beberapa uji data yang akan dilakukan, di antaranya adalah uji Outer Model dan Inner Model. Evaluasi model pengukuran (outer model) dilakukan untuk menilai validitas dan reliabilitas model. Outer model dengan indikator refleksif dievaluasi melalui validitas covergent dan discriminant dari indikator pembentuk konstruk laten dan composite reliability serta cronbach alpha untuk blok indikatornya. Sedangkan evaluasi model struktural (inner model) bertujuan untuk memprediksi hubungan antar variabel laten. Inner model dievaluasi dengan melihat besarnya variance yang dijelaskan yaitu dengan melihat nilai $R$ - square untuk konstruk laten endogen, dan average variance extracted untuk predictiveness dengan menggunakan prosedur resampling seperti botstrapping untuk memperoleh stabilitas dari estimasi.
HASIL

PENELITIAN

DAN

PEMBAHASAN

Tabel 2. Nilai Loading Factor Akhir

\begin{tabular}{|c|c|c|}
\hline Variabel & $\begin{array}{l}\text { Kode } \\
\text { Item }\end{array}$ & $\begin{array}{l}\text { Loading } \\
\text { Factor }\end{array}$ \\
\hline \multirow{5}{*}{$\begin{array}{l}\text { Turnover } \\
\text { Intention }\end{array}$} & T1 & 0,895 \\
\hline & $\mathbf{T} 2$ & 0,936 \\
\hline & $\mathbf{T 3}$ & 0,801 \\
\hline & KP1 & 0,907 \\
\hline & KP2 & 0,926 \\
\hline \multirow[t]{5}{*}{$\begin{array}{l}\text { Kepuasan } \\
\text { Pelatihan }\end{array}$} & KP3 & 0,801 \\
\hline & KP4 & 0,910 \\
\hline & KP5 & 0,919 \\
\hline & KG1 & 0,779 \\
\hline & KG2 & 0,705 \\
\hline \multirow{11}{*}{$\begin{array}{c}\text { Kepuasan } \\
\text { Gaji }\end{array}$} & KG3 & 0,732 \\
\hline & KG4 & 0,714 \\
\hline & KG5 & 0,804 \\
\hline & KG7 & 0,705 \\
\hline & KK1 & 0,832 \\
\hline & KK2 & 0,904 \\
\hline & KK3 & 0,789 \\
\hline & KK4 & 0,846 \\
\hline & KK5 & 0,701 \\
\hline & KK6 & 0,943 \\
\hline & KK7 & 0,936 \\
\hline \multirow{9}{*}{$\begin{array}{c}\text { Kepuasan } \\
\text { Kerja }\end{array}$} & KK8 & 0,841 \\
\hline & KK9 & 0,798 \\
\hline & KK10 & 0,960 \\
\hline & KK11 & 0,812 \\
\hline & KK12 & 0,938 \\
\hline & KK13 & $\mathbf{0 , 8 2 3}$ \\
\hline & KK14 & 0,767 \\
\hline & KK15 & 0,804 \\
\hline & KK16 & 0,732 \\
\hline
\end{tabular}




\begin{tabular}{ccc}
\hline & KO2 & $\mathbf{0 , 7 3 6}$ \\
& KO4 & $\mathbf{0 , 8 2 6}$ \\
& KO5 & $\mathbf{0 , 8 9 0}$ \\
KO6 & $\mathbf{0 , 7 9 1}$ \\
Komitmen & KO8 & $\mathbf{0 , 8 9 2}$ \\
Organisasional & KO9 & $\mathbf{0 , 9 0 3}$ \\
& KO12 & $\mathbf{0 , 7 9 4}$ \\
& KO13 & $\mathbf{0 , 9 4 5}$ \\
& KO15 & $\mathbf{0 , 9 4 4}$ \\
\hline Sumber: Hasil SmartPLS 3.2.8 (2019)
\end{tabular}

\section{Outer Model}

Convergent Validity

Convergent validity diukur dengan menggunakan parameter outer loading dan AVE (Average Variance Extraced). Ukuran refleksif individual dikatakan berkorelasi jika nilai lebih dari 0,7 dengan konstruk yang ingin diukur (Ghozali \& Latan, 2015).

\section{Validitas Discriminant}

Pada validitas diskriminan salah satu parameter yang akan diuji, yaitu Fornell

\section{Larcker Crietion.}

Hasil parameter pada tabel 3 menunjukan bahwa nilai dari uji diskriminan telah memenuhi kriterianya. Validitas diskriminan menunjukkan sejauh mana sebuah konstruk laten mendiskriminasikan dirinya dengan konstruk laten lainnya.
Tabel 3. Fornell-Larcker Criterion

\begin{tabular}{|c|c|c|c|c|}
\hline & 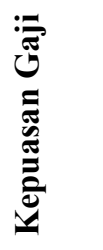 & 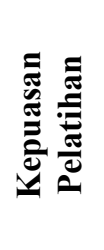 & 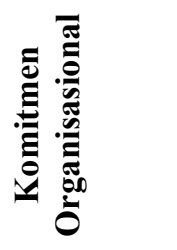 & 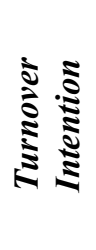 \\
\hline Kepuasan Gaji & 0,743 & & & \\
\hline $\begin{array}{l}\text { Kepuasan } \\
\text { Pelatihan }\end{array}$ & 0,412 & 0,894 & & \\
\hline $\begin{array}{c}\text { Komitmen } \\
\text { Organisasional }\end{array}$ & 0,485 & 0,45 & 0,755 & \\
\hline $\begin{array}{l}\text { Turnover } \\
\text { Intention }\end{array}$ & 0,417 & 0,097 & 0,402 & 0,879 \\
\hline
\end{tabular}

Tabel 4. Composite Reliability

\begin{tabular}{|c|c|c|c|c|}
\hline & 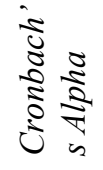 & 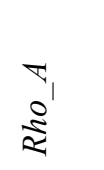 & 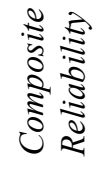 & 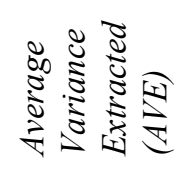 \\
\hline Affective & 0,771 & 0,783 & 0,868 & 0,688 \\
\hline Continuance & 0,844 & 0,871 & 0,897 & 0,689 \\
\hline Kepuasan Gaji & 0,843 & 0,874 & 0,881 & 0,552 \\
\hline $\begin{array}{l}\text { Kepuasan } \\
\text { Pelatihan }\end{array}$ & 0,938 & 0,963 & 0,952 & 0,798 \\
\hline $\begin{array}{l}\text { Komitmen } \\
\text { Organisasional }\end{array}$ & 0,914 & 0,921 & 0,929 & 0,570 \\
\hline Normative & 0,882 & 0,885 & 0,927 & 0,810 \\
\hline $\begin{array}{l}\text { Turnover } \\
\text { Intention }\end{array}$ & 0,858 & 0,919 & 0,910 & 0,772 \\
\hline
\end{tabular}

Reliabilitas

Uji reliabilitas dilakukan untuk membuktikan akurasi, konsistensi, dan ketepatan instrumen dalam mengukur suatu konstruk. Hasil pengujian pada tabel 4 menunjukan bahwa hasil composite reliability menunjukan nilai yang memuaskan yaitu nilai masing-masing variabel di atas nilai minimum 
0,70. Hal tersebut menunjukan konsistensi dan stabilitas instrumen yang digunakan tinggi.

\section{Inner Model}

R-Square

Untuk menilai model goodness of fit dengan PLS, itu dimulai dari nilai R-Square untuk setiap variabel dependen laten.

\section{Signifikansi two-tailed}

Uji hipotesis merupakan analisis kausalitas yang dilakukan untuk mengetahui hubungan antar variabel. Dalam metode PLS, pengambilan keputusan untuk menerima ataupun menolak sebuah hipotesis didasarkan pada nilai signifikansi (P Value), dan nilai $T$ table. Dalam aplikasi SmartPLS, nilai signifikansi bisa diketahui dengan melihan nilai koefisien parameter dan nilai signifikansi t statistik. Skor jalur koefisien atau model bagian dalam ditunjukkan oleh nilai statistikT. Itu harus di atas 1,96 untuk hipotesis twotailed dan di atas 1,64 untuk hipotesis onetailed untuk menguji hipotesis pada alpha 5 persen (Hair et al., 2001).
Tabel 5. Nilai R Square R Square R Square Adjusted

\begin{tabular}{lll}
\hline Affective & 0,774 & 0,772 \\
Continuence & 0,800 & 0,798 \\
$\begin{array}{l}\text { Komitmen } \\
\text { Organisasional }\end{array}$ & 0,331 & 0,316 \\
Normative & 0,799 & 0,797 \\
$\begin{array}{l}\text { Turnover } \\
\text { Intention }\end{array}$ & 0,257 & 0,235 \\
\hline
\end{tabular}

Sumber: Hasil SmartPLS 3.2.8 (2019)

Tabel 6. Rangkuman Hasil Uji Hipotesis

\begin{tabular}{|c|c|c|c|}
\hline \multicolumn{4}{|c|}{ Pengaruh Langsung } \\
\hline & Hipotesis & $\begin{array}{c}\text { Nilai } \\
T\end{array}$ & Hasil \\
\hline H1 & $\begin{array}{lr}\text { Komitmen } & \text { Organisasional } \\
\text { berpengaruh } & \text { negatif } \\
\text { terhadap turnover intention }\end{array}$ & 4,172 & Signifikan \\
\hline $\mathrm{H} 2$ & $\begin{array}{lr}\text { Kepuasan } & \text { Pelatihan } \\
\text { berpengaruh } & \text { negatif } \\
\text { terhadap turnover } & \text { intention }\end{array}$ & 2,509 & Signifikan \\
\hline $\mathrm{H} 3$ & $\begin{array}{l}\text { Kepuasan Gaji berpengaruh } \\
\text { negatif terhadap turnover } \\
\text { intention }\end{array}$ & 3,707 & Signifikan \\
\hline \multicolumn{4}{|c|}{ Pengaruh tidak Langsung } \\
\hline & Hipotesis & $\begin{array}{c}\text { Nilai } \\
\mathbf{T}\end{array}$ & Hasil \\
\hline $\mathrm{H} 4$ & $\begin{array}{l}\text { Komitmen organisasional } \\
\text { memediasi pengaruh } \\
\text { kepuasan pelatihan terhadap } \\
\text { turnover intention }\end{array}$ & 3,030 & Signifikan \\
\hline H5 & $\begin{array}{lr}\text { Komitmen } & \text { organisasional } \\
\text { memediasi } & \text { pengaruh } \\
\text { kepuasan gaji terhadap } \\
\text { turnover intention }\end{array}$ & 2,062 & Signifikan \\
\hline
\end{tabular}

Sumber: Hasil SmartPLS (2019) 


\section{$\mathrm{H}_{1}$ : Pengaruh Komitmen Organisasional}

\section{Terhadap Turnover Intention}

Komitmen organisasi berpengaruh negatif dan signifikan terhadap turnover intention. Apabila semakin tinggi tingkat komitmen organisasi suatu perusahaan, maka niat berpindah pekerjaan yang dimiliki oleh karyawan tersebut akan semakin rendah, sebaliknya apabila tingkat komitmen organisasi karyawan tersebut rendah, maka semakin tinggi niat berpindah pekerjaan yang dimiliki oleh karyawan tersebut. Hasil penelitian ini sejalan dengan penelitian yang dilakukan oleh Srimindarti, Oktaviani, \& Hardiningsih (2017) menunjukkan jika karyawan berkomitmen pada organisasi, mereka akan mempertahankan keanggotaan dalam organisasi dan tidak akan mencari pekerjaan lain.

\section{$\mathrm{H}_{2}$ : Pengaruh Kepuasan Pelatihan}

\section{Terhadap Turnover Intention}

Kepuasan pelatihan berpengaruh negatif dan signifikan terhadap turnover intention. Hasil penelitian menunjukan bahwa kepuasan pelatihan berpengaruh negatif dan signifikan terhadap turnover intention. Hal ini berarti bahwa karyawan yang merasa puas terhadap pelatihan yang dilakukan oleh hotel tidak akan berfikir untuk meninggalkan hotel tersebut. Hasil penelitian ini sejalan dengan penelitian yang dilakukan oleh Memon, Salleh, \& Baharom (2016) dan Gunawan, Sukmawati, \& Vitayala (2018) menunjukan bahwa pelatihan dianggap membantu karyawan untuk melakukan pekerjaan mereka dengan lebih baik, sehingga meningkatkan kepuasan karyawan dengan pelatihan dan pada akhirnya akan meningkatkan rasa kewajiban mereka terhadap perusahaan.

\section{$\mathrm{H}_{3}$ : Pengaruh Kepuasan Gaji Terhadap Turnover Intention}

Kepuasan gaji berpengaruh negatif dan signifikan terhadap turnover intention. Perusahaan untuk menarik dan mempertahankan karyawan yang baik dan memotivasi mereka untuk kerja keras dan dedikasi secara efektif mencapai tujuan bisnis, maka perlu memberikan penghargaan untuk memenuhi kebutuhan karyawan. Penelitian yang dilakukan oleh Tnay, Othman, Siong, \& Lim (2013), Singh \& Loncar (2016) dan Salleh \& Memon (2015) menunjukkan bahwa kepuasan gaji memiliki hubungan yang negatif dengan intensi turnover, intensi turnover diturunkan dengan cara menaikan kepuasan gaji pada karyawan. 
$\mathrm{H}_{4}$ : Pengaruh komitmen organisasional dalam memediasi hubungan variabel kepuasan pelatihan dan turnover intention

Komitmen organisasi memediasi pengaruh kepuasan pelatihan terhadap turnover intention. Pelatihan dianggap membantu karyawan untuk melakukan pekerjaan mereka dengan lebih baik, sehingga meningkatkan kepuasan karyawan dengan pelatihan dan pada akhirnya akan meningkatkan rasa kewajiban mereka terhadap organisasi. Kepuasan pelatihan mempunyai hubungan yang positif terhadap komitmen organisasional, dan komitmen organisasional mempunyai hubungan yang negatif dengan turnover intention (Memon, Salleh and Baharom, 2017).

\section{$\mathrm{H}_{5}$ : Pengaruh komitmen organisasional dalam memediasi hubungan variabel kepuasan gaji dan turnover intention}

Komitmen organisasional memang memediasi kepuasan pelatihan terhadap turnover intention secara moderat. Artinya, peran kepuasan gaji akan lebih signifikan ketika terlebih dahulu melalui komitmen organisasional untuk menunjukkan kinerja bisnis yang baik. Hasil ini sejalan dengan penelitian Hayati, Charkhabi, Kalantari, \&
Paola (2015) menyimpulkan kepuasan gaji mempunyai efek langsung dan tidak langsung terhadap keinginan karyawan untuk pindah kerja dengan komitmen organisasional sebagai mediasi hubungan keduanya. Kompensasi yang diberikan secara adil dan sesuai beban pekerjaan akan membuat karyawan merasa dihargai dan dibutuhkan. Hal ini tentunya dapat membuat karyawan bekerja secara maksimal dan mendukung semua aktivitas yang dilakukan oleh perusahaan.

\section{KESIMPULAN DAN SARAN}

\section{Kesimpulan}

Aset yang sangat penting dan sangat berarti bagi organisasi sekarang bukanlah hanya dari segi fisik saja, seperti keuangan dan sumber daya fisik lainnya, melainkan juga modal manusia (human capital). Turnover intention bisa menjadi halangan bagi organisasi untuk dapat mencapai tujuan strategis yang dinginkannya. Temuan penelitian ini mengindikasikan bahwa kepuasan pelatihan, kepuasan gaji, komitmen organisasional merupakan faktor-faktor yang sangat penting yang bisa memprediksi keinginan karyawan untuk meninggalkan perusahaan. Komitmen organisasional terbukti 
berpengaruh negatif dan signifikan terhadap turnover intention karyawan hotel bintang tiga di kota Padang. Kepuasan pelatihan terbukti berpengaruh negatif dan signifikan terhadap turnover intention karyawan hotel bintang tiga di kota Padang. Kepuasan gaji terbukti berpengaruh negatif dan signifikan terhadap turnover intention karyawan hotel bintang tiga di kota Padang. Padang. Serta, komitmen organisasional terbukti memiliki peran mediasi secara parsial terhadap hubungan antara kepuasan pelatihan dan kepuasan gaji terhadap turnover intention pada karyawan hotel bintang tiga di kota Padang.

\section{Saran}

Dalam penelitian ini, peneliti memiliki saran untuk penelitian selanjutnya yaitu:

1. Penelitian selanjutnya dapat menambahkan variabel independen lainnya, seperti keamanan kerja, tanggung jawab, kesempatan karir dan lain-lain.

2. Dalam proses pengambilan data, disarankan tidak menggunakan metode online. Penelitian hendaknya dilakukan langsung kepada karyawan-karyawan hotel untuk diisi dan perlunya melakukan wawancara secara langsung dengan responden dalam pengisian kuisoner sehingga jawaban kuisioner lebih akurat dan mencerminkan jawaban yang sebenarnya. 


\section{DAFTAR PUSTAKA}

As'ad, M. (2004). Psikologi Industri: Seri Ilmu Manajemen Sumber Daya Manusia. Yogyakarta: Liberty.

Bulut, C., \& Culha, O. (2010). The Effects of Organizational Training on Organizational Commitment. International Journal of Training and Development.

Davoud Hayati, Charkhabi, M., Kalantari, D., \& Paola, F. D. (2015). The Effect of Pay Satisfaction on Turnover Intention: Mediating Role of Job Satisfaction and Organizational Commitment.

Ghayas, M. M., \& Siddiqiu, S. J. (2012). Impact of Job Satisfaction on Turnover Intentions in the Pharmaceutical Industry of Karachi. South Asian Journal of Management Sciences.

Ghozali, I., \& Latan, H. (2015). Partial Least Square: Konsep, Teknik dan Aplikasi menggunakan SmartPLS 3.0 untuk Penelitian Empiris. 2nd Edn. Semarang: Badan Penerbit UNDIP.

Hair, J. F., Black, W. C., Babin, B. J., \& Anderson, R. E. (2010). Multivariate Data Analysis, 7th ed. Pearson Pretince Hall. New Jersey.

Hasibuan, M. S. (2002). Manajemen Sumber Daya Manusia. Jakarta: Bumi Aksara.

Hsiao, H.-C., Chang, J.-C., \& Tu, Y.-1. (2012). The influence of hospital organizational culture on organizational commitment among nursing executives. African Journal of Business management.

Huang, W.-R., \& Su, C.-H. (2016). The mediating role of job satisfaction in the relationship between job training satisfaction and turnover intentions. Industrial and Commercial Training.

Ismail, A., \& Razak, M. R. (2016). Effect of Job Satisfaction on Organizational Commitment. Management \& Marketing, Volume XIV.

Javad, S., \& K., P. R. (2018). Differential impact of pay satisfaction dimensions on job performance and turnover intentions in pay for performance systems: The mediating role of affective commitment. Asian Journal of Empirical Research .

Juhdi, N., Pa'wan, F., \& Hansaram, R. M. (2013). HR practices and turnover intention: the mediating roles of organizational commitment and organizational engagement in a selected region in Malaysia. The International Journal of Human Resource.

Luz, C. M., Paula, S. L., \& Oliveira, L. M. (2016). Organizational Commitment, Job Satisfaction and their Possible Influence on Intent to Turnover. 
Malek, K., Kline, S. F., \& DiPietro, R. (2018). The Impact of Manager Training on Employee Turnover Intentions.

Mediana, E., Prasetya, A., \& Sulistyo, C. W. (2018). Pengaruh Gaya Kepemimpinan dan Budaya Organisasi Terhadap Turnover melalui Kepuasan Kerja Karyawan Pada PT. Muara Wisesa Samudera di Jakarta.

Memon, M. A., Salleh, R., \& Baharom, M. N. (2016). he link between training satisfaction, work engagement and turnover intention. European Journal of Training and Development.

Nelson, J. A., \& Daniels, M. K. (2014). Leadership, Perceptions, and Turnover Intentions: Why Stay? Electronic Journal of Business Ethics and Organizational Studies.

Putri, M. N., \& Rivai, H. A. (2019). Pengaruh job insecurity, kepuasan kerja, dan komitmen organisasional terhadap intensi turnover pada dosen institut teknologi padang. Jurnal Manajemen, $35-48$.

Rivai, H. A. (2015). Link Between Justice Perceptions, Job Satisfaction, Affective Commitment, and Turnover Intent: A Survey From Private Hospitals in Indonesia. Proceedings of the Australasian Conference on Business and Social Sciences .

Saeed, I., Waseem, M., Sikander, S., \& Rizwan, M. (2014). The relationship of Turnover intention with job satisfaction, job performance, Leader member exchange, Emotional intelligence and organizational commitment . International Journal of Learning and Development.

Salleh, R., \& Memon, M. A. (2015). A Review on the Effects of Pay Satisfaction on Employee Engagement and Turnover: A Proposed Mediating Framework. International Business Management, 344-348.

Schmidt, S. W. (2007). The Relationship Between Satisfaction with Workplace Training and Overall Job Satisfaction. Human Resource Development Quarterly.

Shen, L. L. (2014). Can training promote employee organizational commitment? The effect of employability and expectation value. Nankai Business Review International.

Singh, P., \& Loncar, N. (2017). Pay Satisfaction, Job Satisfaction and Turnover Intent. 
Siwi, G., Taroreh, R. N., \& Dotulong, L. O. (2016). Pengaruh Kepuasan Gaji, Promosi Jabatan, Komitmen Organisasi Terhadap Turnover Intention Karyawan RSU GMIM Pancaran Kasih Manado. Jurnal EMBA.

Srimindarti, C., Oktaviani, R. M., \& Hardiningsih, P. (2017). Antecedents of Job Satisfaction and the Influence on Turnover Intention .

Subramanian, I. D., \& Shin, Y. N. (2013). Perceived Organizational Climate and Turnover Intention of Employees in the Hotel Industry. World Applied Sciences Journal 22 (12), 1751-1759.

Susetyo, A. (2016). Pengaruh Job Satisfaction dan Pay Satisfaction Terhadap Turnover Intention Karyawan dengan Komitmen Organisasional Sebagai Variabel Intervening . Jurnal Fokus Bisnis.

Tnay, E., Othman, A. E., Siong, H. C., \& Lim, S. L. (2013). The influences of job satisfaction and organizational commitment on turnover intention. .

Yousef, D. A. (2017). Organizational Commitment, Job Satisfaction and Attitudes toward Organizational Change: A Study in the Local Government.

Yücel, I. (2012). Examining the Relationships among Job Satisfaction, Organizational Commitment, and Turnover Intention: An Empirical Study. International Journal of Business and Management. 